\title{
Anti-cancer, Anti-inflammatory, Cytotoxic and Biochemical Activities of a Novel Phosphonotripeptide Synthesized from Formyl Pyrazolofuran using TUBU as Condensing Agent
}

\author{
Nabil H. Ouf ${ }^{2}$, Mohamed A.Hamed ${ }^{* 1}$, Ibrahim El Sayed ${ }^{1}$, Mohamed I. Sakeran ${ }^{3}$ \\ ${ }^{1 * 3}$ Department of Chemistry, Faculty of Science, Tanta University, Tanta 31527, Egypt. \\ ${ }^{1}$ Department of Chemistry, Faculty of Science, EL Menoufeia University, Shebin El Koom, Egypt. \\ ${ }^{2}$ Department of Chemistry, Faculty of Science, Zagazig University, Zagazig, Egypt. \\ ${ }^{2,3}$ Department of Chemistry and Biochemistry, Faculty of Science, Tabuk University, Tabuk, Saudi Arabia \\ Kingdom. \\ Corresponding author email: msakran2011@gmail.com
}

\begin{abstract}
A novel and mild protocol for the synthesis of phosphonotripeptide 16 were achieved from novel formylpyrazolofuran 3 , benzyl carbamate $\mathbf{5}$, triphenyl phosphite $\mathbf{6}$ by Birum-Oleksyszyn reaction using copper (II) trifliate as Lewis acid catalyst in dry dichloromethane at room temperature which synthesis of novel N-benzyloxy-a-aminophosphonate 7 . A mechanism for this condensation reaction is proposed. Cleavage of the $\mathrm{N}$-benzyloxy carbonyl group under acid hydrolysis afford the free $\alpha$-aminophosphonate 9 in quantitative yield. This in turn, by reaction with $\mathrm{N}$-phthaloylglycine 12 via TUBU to phthalimido group 13.Cleavage of phthalimido group under hydrazinedihydrochloride afford free peptide 14 the result phosphonotripeptide 16 obtained by the reaction of free peptide with bioactive cyclic moiety- $\mathrm{COCl} 15$. The structures of all new compounds were established by IR, ${ }^{1} \mathrm{HNMR}$ and mass spectral data. Also anti-cancer, anti-inflammatory and biochemical activities of all these compounds were reported.
\end{abstract}

\section{Indexing terms/Keywords}

a-aminophosphonate; N-phthaloylglycine; TUBU; hydrazinedihydrochloride; antiinflamatory activity

\section{Council for Innovative Research}

Peer Review Research Publishing System

\section{Journal: Journal of Advances in Chemistry}

\author{
Vol. 6, No. 3 \\ editor@cirworld.com \\ www.cirworld.com, member.cirworld.com
}




\section{Introduction}

Phosphonotripeptides have been found to exhibit a wide range of biological activities to the best of our knowledge there are no papers reports on the preparation of Phosphonotripeptide biconjugates. We focused on formyl pyrazolofuran because it is important class of compounds and attracted widespread. Attention due to their pharmacological properties, being reported to have a large spectrum of biological effects, anti-cancer [1-3]. The present work was aimed to synthesize novel phosphonotripeptide containing pyrazolofuran and $\mathrm{N}$-protected phthalloyl glycine in order to find new anticancer agent. The general method for synthesis of diphenyl a-aminophosphate is the three component reaction of formyl pyrazolo furan, carbamate and triphenylphosphite in organic solvent by one pot Birum-Oleksyszyn reaction [4] according to Scheme 1.a-aminophosphate converted by the deprotection with the appropriate acid condition into the respective free a-aminophosphonate, this is in turn, by reaction with N-protected phthalloyl glycine [5] via TUBU to phthalimido group [6] which by the cleavage of phthalimido group turn to free peptide via hydrazinedihydrochloride [7].The novel phosphinotripeptide afforded by the coupling of N-protected acid chloride with phosphonodipeptide[8].

\section{1-Results and Discussion}

\subsection{Chemistry}

In our efforts to prepare organophosphorous compounds to be employed as novel biologically active agents, we focused on development of a new three-component synthesis of $\mathrm{N}$-protected a-aminophosphate from novel 4-formyl-1-phenyl-3furyl pyrazole, benzyl carbamate triphenylphosphite and Lewis acid. The synthesis of aldhyde needed for this study is achieved according to the following synthetic protocol using Vilsmeier-Haack (VH) reagent. The wide biological application of 4-formyl-1-phenyl-3-furyl pyrazole prompted to undertake the synthesis of $\alpha$-aminophosphate bearing pyrazole moiety.

The synthesis of 4 -formyl pyrazole from the double formylation of hydrazone $\mathbf{3}$ with Vilsmeier-Haack $(\mathrm{VH})$ reagent. To this end the intermediate phenyl hydrazone 3 were in situ-synthesized in almost quantitative yields by the reaction of phenyl hydrazine 1 and acetyl furan 2 . The reaction of 3 was carried out at $70^{\circ} \mathrm{C}$ for $6 \mathrm{~h}$. using three equivalents of $\mathrm{POCl}_{3}$ and dry DMF $(\mathrm{VH})$ reagent affording novel 1-phenyl-3-furyl pyrazole-4-carboxaldhyde 4 in very good yield. It should be noted that 4 cannot be obtained if the DMF is not anhydrous . we started the next step to apply one-pot three component synthesis of diphenyl $\alpha$-aminophosphonate 7 via nucleophilic addition of triphenyl phosphite 6 into an amine formed from condensation of 1-phenyl-3-furyl pyrazole-4-carboxaldhyde $\mathbf{4}$ with carbamate $\mathbf{5}$ in dry solvent as dichloromethane $\left(\mathrm{CH}_{2} \mathrm{Cl}_{2}\right)$ at room temperature in the presence of cuppor triflate according to (Scheme 1). The removal of nitrogen protecting group is well known in the art of organic synthesis. the ammonium hydrobromide 8 were obtained after deprotection of benzyloxy carbonyl group of benzyl carbamate with solution of hydrogen bromide in acetic acid at room temperature in a short time (0.5-2h).transformation of ammonium bromide into free amine 9 was achieved. Triethyl amine was chosen, in this case, to preferentially saponify the corresponding salt even though completion of the reaction required a little longer time. thus, the desired free diphenyl $\alpha$-aminophosphonate were obtained by treating hydrobromide with triethyl amine in anhydrous THF. Filteration of the salt followed by evaporation of low boiling substance under reduced pressure resulted in the free amine 9 .Synthesis of the phosphinopeptide began with condensation of phthalic anhydride $\mathbf{1 0}$ with glycine $\mathbf{1 1}$ at high temperature $\geq 180^{\circ} \mathrm{C}$ under solvent free conditions it should be noted that both of the reactants should be well ground and mixed evenly to ensure entire transformation of starting materials into the $\mathrm{N}$-phthaloyl product 12 . At room temperature $\mathrm{N}$ protected glycine 12 is readily coupled with free diphenyl $\alpha$-aminophosphonate 9 in the presence of $2(1 \mathrm{H}$-benzotriazol-1yl)1,1,3,3-tetramethyl uroanium tetrafloroborate (TBTU) as a peptide coupling agent to afford the $\mathrm{N}$-protected phosphonodipeptide 13 in high yield. The phthaloyl group in the protected dipeptide 13 was subsequently subjected to cleavage by hydrazinolysis in absolute methanol overnight at room temperature to deliver the free amine containing phosphonopeptide 14 .

To prepare phosphonotripeptide, chlorination of $\mathrm{N}$-protected glycine $\mathbf{1 2}$ by thionyl chloride was achieved under solventfree condition at $60^{\circ} \mathrm{C}$ to afford 15 in high yields as illustrated in Scheme 1. The excess of thionyl chloride was removed at $55^{\circ} \mathrm{C}$.It was found that high temperature would cause partial decomposition of the product. The crude acid chloride generated was used immediately in the next step after the dissolution in anhydrous $\mathrm{CH}_{2} \mathrm{Cl}_{2}$. The coupling of acid chloride 15 with phosphonodipeptide $\mathbf{1 4}$ proceeded smoothly on ice-path in the presence of triethyl amine. The pure product $\mathbf{1 6}$ was obtained in higher yield after recrystalization from a mixture of dichloromethane/diethyl ether.

\subsection{Biological studies}

\subsubsection{Anticancer Activity}

It was observed through analysis that: The dipeptide $\mathbf{1 6}$ had the highest cytotoxic activity against breast carcinoma $(\mathrm{MCF} 7)$ cell line $\left(\mathrm{IC}_{50}\right)=(0.534 \mu \mathrm{g} / \mathrm{ml})$ and also against colon carcinoma cell line $\left(\mathrm{IC}_{50}\right)=(0.629 \mu \mathrm{g} / \mathrm{ml})$ as shown in table 1.Compound 4 was active against colon carcinoma cell line $\left(\mathrm{IC}_{50}=0.781 \mu \mathrm{g} / \mathrm{ml}\right)$ had $I \mathrm{C}_{50}$ similar to that of standard drug and showed high activity against breast carcinoma cell line $\left(\mathrm{IC}_{50}=0.743 \mu \mathrm{g} / \mathrm{ml}\right)$.Compounds 7,9,13, 14 showed high activity against breast carcinoma cell line and colon carcinoma cell line $\left(\mathrm{IC}_{50}=0.865,0.858\right.$ and $\left.0.896 \mu \mathrm{g} / \mathrm{ml}\right)$ respectively for breast carcinoma and $\left(\mathrm{IC}_{50}=0.868,890\right.$ and $\left.750 \mu \mathrm{g} / \mathrm{ml}\right)$ for colon carcinoma.

\subsection{2-Anti-inflammatory activity}

From Table 2 it appeared that compound 16 at doses of 40,60 and $80 \mathrm{mg} \%$ has significant anti-inflammatory activity compared with indomethacin as a reference drug at 1, 2, 3 and 4 hours. 


\subsection{3-Acute toxicity studies $\left(\mathrm{LD}_{50}\right)$}

The acute toxicity of compound $\mathbf{1 6}$ in adult mice were tested. The results are given in Table $\mathbf{3}$ shows that i.p. injection of compound 16 in doses of $80,120,200,250$ and 350 and $400 \mathrm{mg} / 100 \mathrm{~g}$ b.w. resulted in mortalities of $0,1,2,4,8$ and 10 respectively.

\subsection{4- Biochemical studies}

Administration of compound 16 orally to the rats at dose of $300 \mathrm{mg} / \mathrm{kg} \mathrm{b.w.} \mathrm{for} 15$ days showed non-significant differences in liver enzymes AST, ALT, ALP, LDH, y -GT and serum MDA as compared with the control group Table 4.

\section{2- Exprimental}

\section{2-1. Chemistry}

All melting points were taken on Electrothermal IA 9000 series digital melting point apparatus. The IR spectra (KBr) were recorded on a PYEUNICAM spectrophotometer. The ${ }^{1} \mathrm{HNMR}$ spectra was recorded at $300 \mathrm{MHz}$ on a Perkin Elmer R12B Spectrometer using TMS as an internal standard. The mass spectra were performed using VG2AB-3F spectrometer (70 eV). All reactions were followed by TLC (silica gel, aluminum sheets 60 F254; Merck).

\subsubsection{General procedure for the preparation of 1-phenyl-3-furyl pyrazol 4-Carboxaldyhde}

To $(0.01 \mathrm{~mol})$ methylfuryl ketone hydrazone, $(0.01 \mathrm{~mol})$ Vilsmeier reagent $\left(14.6 \mathrm{ml} \mathrm{DMF}\right.$ and $\left.19.1 \mathrm{ml} \mathrm{POCl}_{3}\right)$ was added drop wise with stirring for one hour- The reaction mixture was refluxed for 6 hours at $70-80^{\circ} \mathrm{C}$. then hydrolyzed on icewater mixture, neutralized by $5 \% \mathrm{NaOH}$ solution till $\mathrm{pH}=4$, the solid formed was filtered off, washed with water, dried and recrystallized from isopropanol.

\subsubsection{General procedure for the preparation of $\alpha$-aminophosphonate.}

benzyl carbamates $(1 \mathrm{mmol})$, aldhyde $(1.2 \mathrm{mmol})$ and $\mathrm{P}(\mathrm{OPh})_{3}(1 \mathrm{mmol})$ were dissolved in well dried $\mathrm{CH}_{2} \mathrm{Cl}_{2}(2 \mathrm{ml}) . \mathrm{The}$ Lewis acid $\mathrm{Cu}(\mathrm{OTf})_{2}(10 \mathrm{~mol} \%)$ was added in one portion as $1 \mathrm{M}$ solution in anhydrous $\mathrm{CH}_{2} \mathrm{Cl}_{2}$, This mixture was stirred at room temperature until TLC analysis showed the complete consumption of benzyl carbamate. then $\mathrm{CH}_{2} \mathrm{Cl}_{2}$ was evaporated and the residue dissolved in $\mathrm{MeOH}(10 \mathrm{ml})$. The product was precipitated from this solution by storing at $-20^{\circ} \mathrm{C}$ for 3- $6 \mathrm{~h}$., followed by the collection of the precipitate by the filtration .Recrystalization was carried out by dissolving the product in $\mathrm{CHCl}_{3}(5 \mathrm{ml})$, Concentration the $\mathrm{CHCl}_{3}$ under reduced pressure, and adding $\mathrm{MeOH}(8 \mathrm{ml})$ to the residue . This solution was stored at $-20^{\circ} \mathrm{C}$ for 3-6 h., the precipitated product was filtered off and dried under reduced pressure.

\subsubsection{General procedure for cleavage of benzyloxy carbonyl group.}

To $(0.01 \mathrm{~mol})$ benzyloxy carbonyl group, $(0.01 \mathrm{~mol}) \mathrm{HBr} / \mathrm{HOAc}$ was added drop wise with stirring . After complete addition , the reaction mixture was left to stirred at r.t. for $1 \mathrm{~h}$. The solid formed was filtered off, washed with methanol(10 ml) and dried under reduced pressure.

\subsection{4 preparation of phthaloylglycine}

Phthalic anhydride $(0.01 \mathrm{~mol})$, glycine $(0.1 \mathrm{~mol})$ was heated in sand path for $3 \mathrm{~h}$. After the reaction completed added(10 $\mathrm{ml})$ ethanol and filtered the white solid, dried, recrystallization was carried out by using $\mathrm{H}_{2} \mathrm{O}$.

\subsubsection{General procedure for the preparation of phthalimido group}

Phthaloylglycine $(1 \mathrm{mmol})$ was dissolved in dry dichloromethane $(15 \mathrm{ml})$,triethylamine $(4 \mathrm{mmol})$ was added, followed by TBTU $(1.1 \mathrm{mmol})$.After the mixture was stirred for $5 \mathrm{~min}$, the appropriate amine $(1.1 \mathrm{mmol})$ dissolved in $2 \mathrm{ml}$ of dichloromethane was dropped into the solution and stirring was continued for $3 \mathrm{~h}$., The solid formed was filtered off, dried. recrystallization was carried out using ethanol.

\subsubsection{General procedure for cleavage of the phthalimido group.}

To a solution of $13(0.6 \mathrm{mmol})$ and hydrazinedihydrochloride $(0.83 \mathrm{~g}, 2.7 \mathrm{mmol})$ in dry methanol $(8 \mathrm{ml})$, a solution of triethyl amine $(0.7 \mathrm{ml}, 5.4 \mathrm{mmol})$ in dry ethanol $(2 \mathrm{ml})$ was added drop wise. The mixture was heated at $40^{\circ} \mathrm{C}$ for $4 \mathrm{~h}$. and then cooled, add water $(30 \mathrm{ml})$ and extracted with ethyl acetate. The solvent was evaporated and the residue was chromatographed on silica gel coloum with dichloromethane/ethyl acetate 1:1 give 14 .

\subsubsection{General procedure for the preparation of Carbonyl chloride of Phthaloylglycine}

Phthaloylglycine $(0.1 \mathrm{~mol})$ and toluene $(50 \mathrm{ml})$ was placed in $250 \mathrm{ml}$ flask, equipped with magnetic stirrer. After dissolving of Phthaloylglycine, $(0.3 \mathrm{~mol})$ of thionyl chloride was added to the reaction mixture. The mixture was refluxed for $6-7 \mathrm{~h}$., with stirring. The volatile compound was removed by rotary evaporation and gave the desired, crude carbonyl chloride which was immediately used to the next step without further purification.

\subsubsection{General procedure for synthesis of phosphonotripeptide}

$(0.1 \mathrm{~mol})$ of carbonyl chloride was dissolved in (15 ml0 dry dichloromethane and placed in the flask (100 ml).The reaction mixture was cooled to $0^{\circ} \mathrm{C}$. and $(0.1 \mathrm{ml})$ of free amino phosphonotripeptide 14 was dissolved in dry $\mathrm{CH}_{2} \mathrm{Cl}_{2}$ and added very slowly with stirring to the carbonyl chloride. Added few drop of $\mathrm{Et}_{3} \mathrm{~N}$ to the mixture. The mixture was stirring until TLC 
analysis showed the complete of the reaction. The volatile compound were removed by rotary evaporation and gave the desired product,filter the precipitate, dried and crystallized from $\mathrm{ETOH}$.

\subsection{9-phenyl-3-furyl pyrazol4-Carboxaldyhde (4)}

m.p. $=150-151^{\circ} \mathrm{C}, \mathrm{IR}(\mathrm{KBr}) \quad v=1600,1510,820,730 \mathrm{Cm}^{-1},{ }^{1} \mathrm{HNMR}\left(400 \mathrm{MHz}, \mathrm{CDCl}_{3}\right), 5=7.4-8.1(\mathrm{~m}, 8 \mathrm{H}, \mathrm{Harom}), 8.7(\mathrm{~S}, 1 \mathrm{H}$, CHpyrazole), 10.25 (S,1H,CHO),MS: $\mathrm{m} / \mathrm{z}=238\left(\mathrm{M}^{+}\right), 209,161$ (base peak).

\subsubsection{0-Diphenyl[(BenzyloxyCarbonyl) amino](1-phenyl 3-furyl pyrazole) methyl phosphonate (7)}

m.p. $\quad 230-231^{0} \mathrm{C}, \mathrm{IR}(\mathrm{KBr}) \quad v=3271(\mathrm{NH}), \quad 1600(\mathrm{C}=\mathrm{N}), 1500(\mathrm{C}=\mathrm{C}), 1232 \quad(\mathrm{P}-\mathrm{O}), 1062(\mathrm{P}-\mathrm{O}-\mathrm{C}) \quad \mathrm{Cm}^{-1}, \quad{ }^{1} \mathrm{HNMR}$ $\left(400 \mathrm{MHz}, \mathrm{CDCl}_{3}\right) \delta=5.05-5.22 \quad\left(\mathrm{~m}, 2 \mathrm{H}, \mathrm{CH}_{2} \mathrm{OC}\right), 5.5-5.69 \quad(\mathrm{~m}, 1 \mathrm{H}, \quad$ CHpyrazole $), 8.6 \quad(\mathrm{~S}, 1 \mathrm{H}, \mathrm{CHpyrazole}) . \quad \delta=6.81-$ 6.98(S,1H,NH),6.78-6.89 (m,5Harom),7.05-7.43 (m,3Hfuran).MS:m/z = 605( $\left.\mathrm{M}^{+}\right)$.

2.1.11-Diphenyl-1-amino[1-phenyl-3-furyl pyrazole) methyl phosphonate (9)

m.p. $=200-201^{0} \mathrm{C}, \mathrm{IR}(\mathrm{KBr}) \quad v=3404(\mathrm{NH}), 1600(\mathrm{C}=\mathrm{N}), 1500(\mathrm{C}=\mathrm{C}), 1232(\mathrm{P}-\mathrm{O}), 1062(\mathrm{P}-\mathrm{O}-\mathrm{C}) \mathrm{Cm}^{-1},{ }^{1} \mathrm{HNMR}(400$

$\left.\mathrm{MHz}, \mathrm{CDCl}_{3}\right) \quad \delta=5.5-3.5(\mathrm{~m}, 1 \mathrm{H}, \quad \mathrm{CHpyrazole}), \quad 5.8-6.0 \quad\left(\mathrm{~d}, 2 \mathrm{H}, \mathrm{NH}_{2}\right)$, 7.05-7.2 (m,15Harom), 7. 417.6(m,3Hfuran), 8.61(S,1H,CHpyrazole),. MS: $\mathrm{m} / \mathrm{z}=470\left(\mathrm{M}^{+}\right)$.

\subsubsection{2-Phthaloyl glycine (12)}

m.p. $=190-191^{0} \mathrm{CIR}(\mathrm{KBr}) \quad v=1500,1610 \mathrm{Cm}^{-1},{ }^{1} \mathrm{HNMR}\left(400 \mathrm{MHz}, \mathrm{CDCl}_{3}\right) \quad \delta=4.2\left(\mathrm{~S}, 2 \mathrm{H}, \mathrm{CH}_{2}\right), 3.3(\mathrm{~S}, 1 \mathrm{H}, \mathrm{OH}), 7.8-7.9$ (m,4Harom). MS: $\mathrm{m} / \mathrm{z}=206\left(\mathrm{M}^{+}\right)$.

\subsubsection{3-Diphenyl-2 [(N-phthaloyl glycine) amino]-1-phenyl-3-furyl pyrazole) methy phosphonate(13)}

m.p. $=320-321^{0} \mathrm{C}, \mathrm{IR}(\mathrm{KBr}) \quad v=3296,1234,1027 \mathrm{Cm}^{-1},{ }_{1}^{1} \mathrm{HNMR}\left(400 \mathrm{MHz}, \mathrm{CDCl}_{3}\right) \delta=4.4-4.42\left(\mathrm{~S}, 2 \mathrm{H}, \mathrm{CH}_{2}\right), 5.1-5.15\left(\mathrm{~m}_{1}, 1 \mathrm{H}\right.$, CHP), 5.7-5.9 (d, 1H, NH), 7.00-7.34 (m,15Harom), MS: m/z = 657( $\left.{ }^{+}\right)$

2.1.14-Diphenyl-2 [(glycinamino)]-1-phenyl-3-furyl pyrazole) methy phosphonate(14):

m.p. $=290-291^{0} \mathrm{C}, \mathrm{IR}(\mathrm{KBr}) \quad v=3400,3295,1234,1027 \mathrm{Cm}^{-1},{ }^{1} \mathrm{HNMR}\left(400 \mathrm{MHz}, \mathrm{CDCl}_{3}\right) \quad \delta=3.4-3.44\left(\mathrm{t}, 2 \mathrm{H}, \mathrm{CH}_{2}\right), 5.0-5.1$ ( $\mathrm{m}, 1 \mathrm{H}, \mathrm{CHP}), 5.7-5.86$ (t, 2H, NH ), 7.05-7.2 (m,15Harom), 7.041-7.6(m,3Hfuran), 8.61(S,1H,CHpyrazole) MS: $\mathrm{m} / \mathrm{z}=527$ $\left(\mathrm{M}^{+}\right)$.

\subsubsection{5-Phthaloyl glycinacyl chloride (15)}

m.p. $=152-154^{0} \mathrm{C}, \mathrm{IR}(\mathrm{KBr}) \quad v=1500,1820 \mathrm{Cm}^{-1},{ }^{1} \mathrm{HNMR}\left(400 \mathrm{MHz}, \mathrm{CDCl}_{3}\right) \quad \delta=4.21-4.33\left(\mathrm{~s}, 2 \mathrm{H}, \mathrm{CH}_{2}\right), 7.8-7.9(\mathrm{~m}, 4 \mathrm{Harom})$. MS: $m / z=223\left(M^{+}\right)$.

\subsubsection{6-Diphenyl-3 phosphonate(16):

m.p. $=360-361^{0} \mathrm{C}, \mathrm{IR}(\mathrm{KBr}) \quad v=3271,1820,1600,1500,1232,1062 \mathrm{Cm}^{-1},{ }^{1} \mathrm{HNMR}\left(400 \mathrm{MHz}, \mathrm{CDCl}_{3}\right) \delta=3.04-3.1\left(\mathrm{~S}, 2 \mathrm{H}, \mathrm{CH}_{2}\right)$, 3.5-3.51 (d,2H, CH $\mathrm{CH}_{2}$, 5.7-5.9 (d, 1H, NH), 8.3-8.31 (S, 1H, NH), 8.60(s,1H,CHpyrazole), 7.05-7.1 (m,10Harom), 7.417.42(m,3Hfuran). MS: $\mathrm{m} / \mathrm{z}=715\left(\mathrm{M}^{+}\right)$.

\section{2-Biological studies}

\subsection{1- Cytotoxic activity evaluation}

The Sulporohodamine B (SRB) assay of Skehan [10] was used to evaluate the cytotoxic activity of the newly synthesized compounds 4, 7, 9,13,14,16 against two cell lines, breast carcinoma(MCF7) and colon carcinoma(HCT116).Cells were plated in 96 -multiwell plates $\left(10^{4}\right.$ cells/well) for $24 \mathrm{~h}$. before treatment with the compound to allow attachment of the cells to the wall of the plate.

Different concentrations of the compounds under test $(0,1,2.5,5$ and $10 \mathrm{mg} / \mathrm{ml})$ were added to the cell monolayer. Triplicate wells were prepared for each dose. Monolayer cells were incubated with the compounds under test for $48 \mathrm{~h}$. at $37^{\circ} \mathrm{C}$ and atmosphere of $5 \% \mathrm{CO}_{2}$. After $48 \mathrm{~h}$., cells were fixed, washed and stained with The Sulporohodamine B stain. Excess stain was washed with acetic acid and then after attached stain was recovered with Tris EDTA buffer. Color intensity was measured in an ELISA reader.IC S0 $_{50}$ value was determined for each tumor cell line for the specified compounds, calculated by an available computerized program, which was defined as the concentration of drug to produce $50 \%$ reduction in the viability relative. The control given compound were recorded in Table 1 .Given compounds were considered significantly inactive when their $\mathrm{IC}_{50}$ values are higher than $10 \mu \mathrm{g} / \mathrm{ml}$.

\subsection{2- Anti-inflammatory activity}

Male albino mice weight around 150- $200 \mathrm{~g}$ were purchased from Faculty of Science, Tanta University, Egypt. They were acclimatized to animal house conditions. Animals were provided with standard diet. The anti-inflammatory activity was 
carried out following the method of Domenjoz, $R$ [11]. Rats were divided into 5 different groups each of 10 animals. At the beginning, the thickness of the left paw was measured. They were treated orally with the tested compounds, at $40 \mathrm{mg} / \mathrm{kg}$ body weight or indomethacin $600 \mathrm{mg} / \mathrm{kg}$ as a reference standard. After one hour of administration, the inflammation was induced by S.C. injection of $0.1 \mathrm{ml}$ of $6 \%$ formalin solution in normal saline. The right hind paw was injected with unequal volume of saline. The difference in thickness between the two paws gave the swelling induced by formalin. The antiinflammatory efficacy was estimated by comparing the swelling of the treated with the control. The difference in thickness was recorded after 1, 2, 3 and 4 hours.

\subsection{3-Acute Toxicity Studies $\left(\mathrm{LD}_{50}\right)$}

Preliminary experiments were carried out on 6 main groups (10 mice/each dose/each group). Compond 16 was injected in different doses to find out the range of doses which cause zero and $100 \%$ mortality of animals. $L D_{50}$ was determined as indicated in Tables 2.

The $\mathrm{LD}_{50}$ was then calculated by the application of the following formula:

$$
L D_{50}=\frac{\mathrm{Dm}-\Sigma(\mathrm{Z} . \mathrm{d})}{\mathrm{n}}
$$

$\mathrm{Dm}=$ The dose by which killed all the mice in the group.

$Z$ = Half the sum of the dead rats from 2 successive groups.

$d=$ The difference between 2 successive doses.

$\mathrm{n}=$ number of animals in each group.

\subsection{4- Biochemical studies}

Administration of compound $\mathbf{1 6}$ orally to the rats at dose of $300 \mathrm{mg} / \mathrm{kg} \mathrm{b.w.} \mathrm{for} 15$ days showed non-significant differences in liver enzymes AST, ALT, ALP, LDH, $\mathrm{Y}-\mathrm{GT}$ and serum MDA as compared with the control group (Table 3).

\subsubsection{1- Experimental Design}

This experiment was carried out to examine the effect of compound 16 on liver enzymes. A solution of $6 \mathrm{~g} \%$ for compound 16 in DMSO was prepared and administrated to rats. Groups of animals each consisting of 6 rats in each were treated daily for 15 days as follows:

Group I: Control (was given similar volume of saline)

Group II: Normal (was given similar volume of DMSO)

Group III: Was treated with compound 16 (300 mg/kg b.w.) dissolved in DMSO orally in a single daily dose [12].

After 10 days of treatment, animals were sacrivised,, blood samples were withdrawn of each animal. The separated blood was used for the estimation of AST, ALT, Y-GT, ALP, LDH and MDA.

\subsubsection{2- Biochemical Assays}

The separated blood was used for the estimation of Serum levels of Aspartate transaminase (AST), Alanine transaminase $(A L T)$ [13], alkaline phosphatase (ALP) [14], Gamma Glutamyltransferase $\gamma-G T$ [15], lactate dehydrogenase [16] and Malondiadhyde as TBARS in serum [17].

\section{Conclusion}

The main objective of this study was to synthesize novel derivatives and exploration their potential cytotoxic activity and measuring some biochemical parameters to assess their safety as anticancer drugs. The results in table 1 showed that compound 16 was the most active one against breast carcinoma (MCF7) cell line and colon carcinoma (HCT116).Also results at table 2 showed that all examined compounds has non-significant differences in liver enzymes AST, ALT, ALP, $\mathrm{LDH}, \mathrm{Y}-\mathrm{GT}$ and serum MDA as compared with the control group.

\section{References}

1- M.A.Kira, M.O.Abdel-Rahman and K.Z.Gadalla, (1969) Tetrahedron let.2109.

2- D.R. Nagargoje, G.R.; jadhav, M.V.Shaikh, S.D.Diwakar, M.S. Shingara, C.H. Gill (2008), Ind. J. Het. Chem., 1853.

3- ClintonR.O, Mason AJ, Stonner F W, Beyler AL, Potts GO, Arnold AJ, (1959) Am.chem.Soc.811513.

4- Storeng, P.; Ritsa,S; Scudiero,D.; Monks A.; MC Mahon,J.; Vistica,D.; Warren,J.T.; Bokesch;H.; Kenney,S.; Boyd,M.R. (1990), J.Natl.Cancer Inst., 821170.

5- Olekesyszyn, J, Subotkowska, L, Mastalerz, P. synthesis 1979,985.(b) Olekesyszyn, J, Tyka,R. Tetrahedron Lett.1977, 18,2823

6- Sikoraiova,J et al., 2002,Tetrahedron Lett. (34): 4747 - 4751 . 
7- Vander Vrkrn et al., 2005, Journal of Medicinal Chemistry, , Vol 48, No. 6.

8- P Dell,Buttero et al., 2003, Tetrahedron Asymmetry (14):3949-3953

9- M. Drag et al, 2005 European Journal of Medicinal Chemistry (40) 764 - 771

10- Skehan P, Storeng R, Scudiero D, Monks A, McMahon J, Vistica D, Warren JT, Bokesch H, Kenney S, Boyd MR. 1990, J Natl Cancer Inst. Jul 4;82(13):1107-12.

11- Domenjoz, R. (1952), (Univ. suarbruchen, Ger.) Schweiz., Med. Wochschr.,82, 1023.

12- Lavergne N, Volkman M, Maki J.E, Yoder R, Trepanier A 2005, Toxicology : 208: 63-72

13- Reitman S, Frankel A., Am JClinPathol. 1975, Am J Clin Pathol. 1975; 28:56-62.

14- King EJ, Armstrong and Varley H. New Delhi: CBS Publisher. 1988; Pp 458.

15- Fiala S, Fiala AE, Dixon B, 1972;. J Nat Can Inst. 48:1393.

16- Buhl SN, Jackson KY.1978. Clin. Chem. 2415: 828-835.

17- Uchiyama M, Mihara M., Anal. Biochem. 1978; 2415: 828-835. 

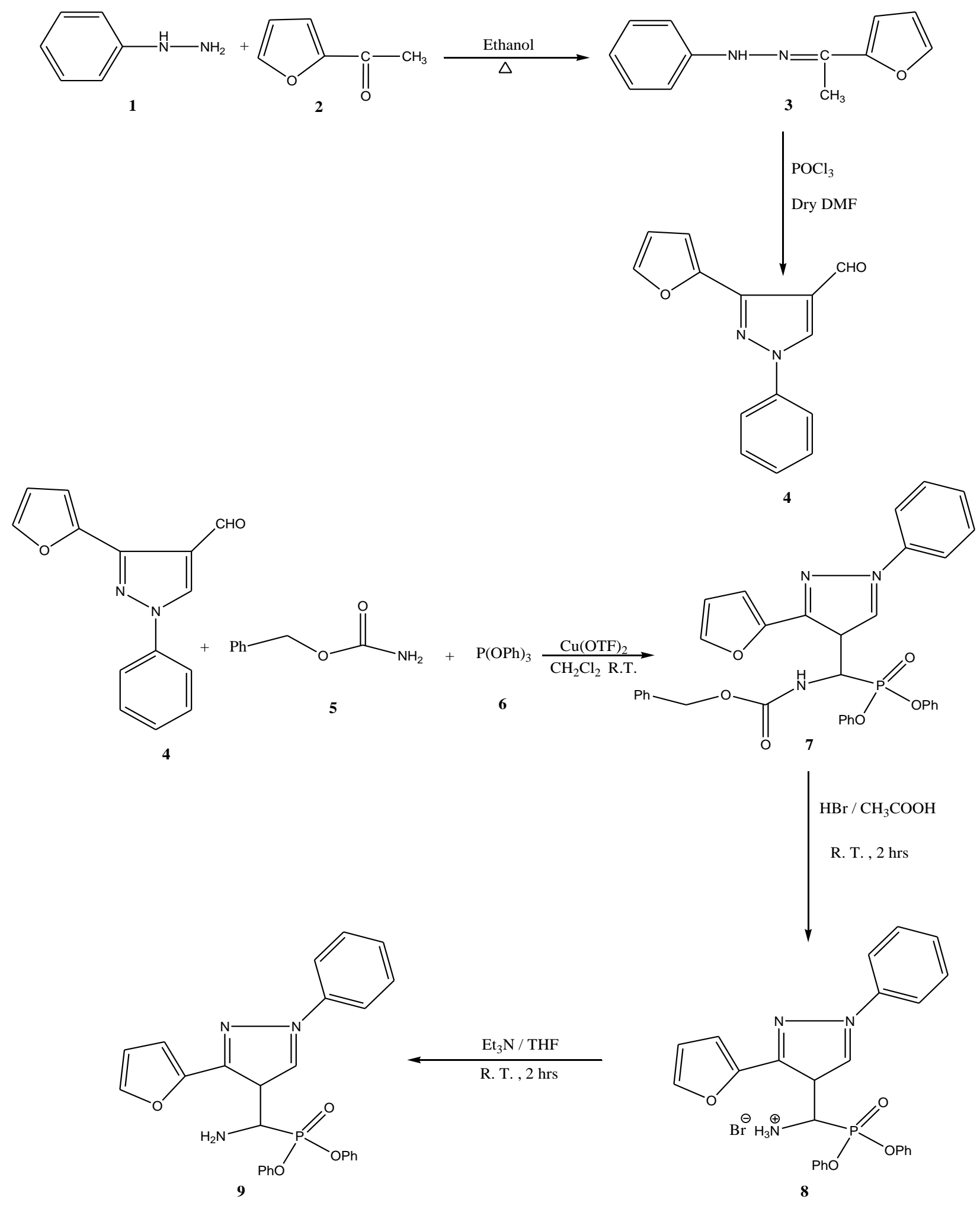


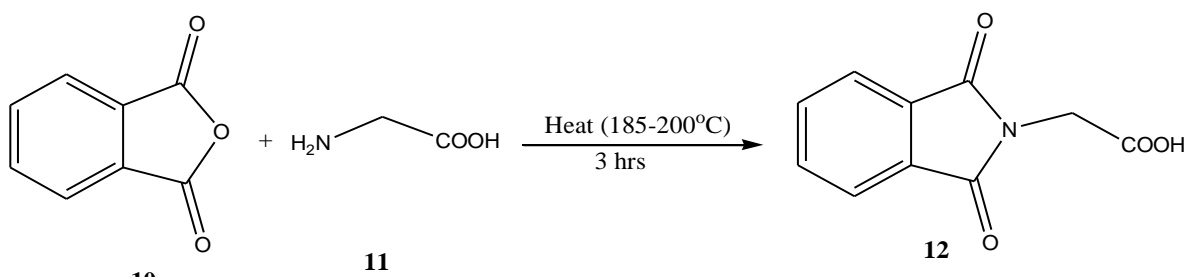

10

11<smiles></smiles><smiles>O=C(CN1C(=O)c2ccccc2C1=O)NC(C1C=NN=C1c1ccco1)P(=O)(Oc1ccccc1)Oc1ccccc1</smiles>

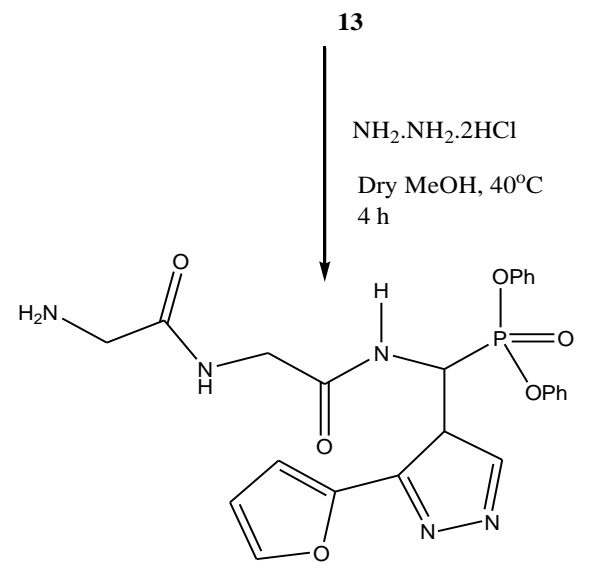

14<smiles>O=C(O)CN1C(=O)c2ccccc2C1=O</smiles>

12
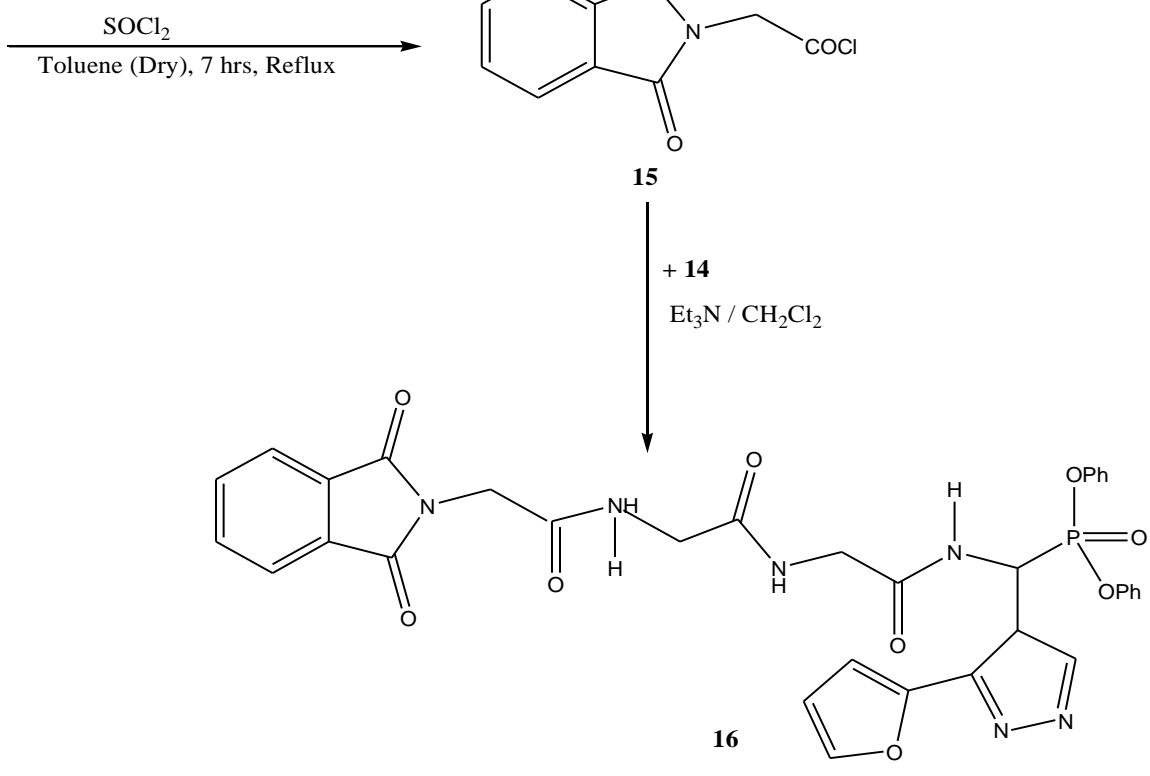

Sheme (1) 
Table (1): Cytotoxic activity of the synthesized compounds against breast carcinoma (MCF7) and colon carcinoma (HCT116) cell lines.

\begin{tabular}{ccc}
\hline Compound No. & \multicolumn{2}{c}{$\mathrm{IC}_{50}$} \\
\hline & Breast carcinoma(MCF7) cell line & Colon carcinoma(HCT116) cell lines. \\
& & \\
4 & 0.743 & 0.781 \\
7 & 0.743 & 0.896 \\
9 & 0.865 & 0.858 \\
13 & 0.858 & 0.868 \\
14 & 0.896 & 0.890 \\
16 & 0.534 & 0.750 \\
Doxorubicin & 0.629 & 0.743 \\
\hline
\end{tabular}

$\mathrm{IC}_{\mathbf{5 0}}$ is a dose required to inhibit the cell growth by $50 \%$

Table (2) : The Anti-inflammatory activity of compound 16 and indomethacin in dose of $0.4,0.6$ and $0.8 \mathrm{mg} / 100$ gm body weight of rats on the inflamed rat paw ( $n=5$ rats). (Mean+S.E).

\begin{tabular}{|c|c|c|c|c|c|}
\hline Groups & Initial thickness & - & Thickness of R & $(\mathrm{mm})$ after & \\
\hline & (zero time) & 1 hour & 2 hours & 3 hours & 4 hours \\
\hline Control & $2.0 \pm 0.0$ & $5.8 \pm 0.23$ & $6.72 \pm 0.31$ & $7.7 \pm 0.31$ & $7.8 \pm 0.32$ \\
\hline Indomethacin & $2.2 \pm 0.17$ & $2.33 \pm 0.23^{a}$ & $2.71 \pm 0.31^{a}$ & $3.7 \pm 0.28^{a}$ & $3.9 \pm 0.24^{a}$ \\
\hline $0.4 \mathrm{mg} / 100 \mathrm{~g} \mathrm{b.w}$ & $2.3 \pm 0.0$ & $3.5 \pm 0.21^{\mathrm{ab}}$ & $4.8 \pm 0.31^{\mathrm{ab}}$ & $5.6 \pm 0.23^{\mathrm{ab}}$ & $5.3 \pm 0.22^{a b}$ \\
\hline $0.6 \mathrm{mg} / 100 \mathrm{~g} \mathrm{b.w}$ & $2.2 \pm 0.0$ & $3.3 \pm 0.23^{a b}$ & $4.6 \pm 0.28^{\mathrm{ab}}$ & $5.5 \pm 024^{\mathrm{ab}}$ & $5.2 \pm 0.24^{\mathrm{ab}}$ \\
\hline $0.8 \mathrm{mg} / 100 \mathrm{~g}$ b.w & $2.2 \pm 0.21$ & $3.0 \pm 0.21^{\mathrm{ab}}$ & $4.4 \pm 0.22^{\mathrm{ab}}$ & $5.2 \pm 2.2^{\mathrm{ab}}$ & $5.0 \pm 0.21^{a b}$ \\
\hline
\end{tabular}

Compared with control, ${ }^{a} p<0.001$

Compared with indomethacin ${ }^{b} p<0.01$

Table (3): Determination of $L D_{50}$ of compounds 14b, 14d, 15 1nd 17 given i.p. in adult mice

\begin{tabular}{|c|c|c|c|c|c|c|}
\hline Compound & Dose(mg/kg) & animals/group & Dead animals & $(\mathrm{Z})$ & (d) & $\overline{\text { (Z.d) }}$ \\
\hline \multirow[t]{6}{*}{16} & 80 & 10 & 0 & 0.5 & 40 & 20 \\
\hline & 120 & 10 & 1 & 8.0 & 50 & 40 \\
\hline & 200 & 10 & 2 & 2 & 70 & 140 \\
\hline & 250 & 10 & 4 & 4 & 80 & 320 \\
\hline & 350 & 10 & 8 & 8 & 90 & 720 \\
\hline & 400 & 10 & 10 & 0 & 00 & 00 \\
\hline
\end{tabular}




$$
L D_{50}=\frac{\mathrm{Dm}-\Sigma(\mathrm{Z} \cdot \mathrm{d})}{\mathrm{n}}
$$

$\mathrm{LD}_{50}$ of compound $16=276 \mathrm{mg} / 100 \mathrm{~g}$. b.w.

Table(4): Serum Levels of AST, ALT, ALP, Y- GT, LDH and MDA in normal and experimental groups of rats

\begin{tabular}{|c|c|c|c|c|c|c|}
\hline Group & $\begin{array}{l}\text { AST } \\
\mathrm{U} / \mathrm{I}\end{array}$ & $\begin{array}{l}\text { ALT } \\
\text { U/I }\end{array}$ & $\begin{array}{c}\text { ALP } \\
\mathrm{U} / \mathrm{I}\end{array}$ & $\begin{array}{c}\mathrm{Y-GT} \\
\mathrm{U} / \mathrm{I}\end{array}$ & $\begin{array}{l}\text { LDH } \\
\mathrm{U} / \mathrm{I}\end{array}$ & $\begin{array}{c}\text { MDA } \\
\mathrm{nmol} / \mathrm{ml}\end{array}$ \\
\hline Normal Saline & $8.6 \pm 1.3$ & $32 \pm 2.5$ & $35.0 \pm 2.6$ & $5.3 \pm 1.8$ & $223.0 \pm 6.22$ & $5.22 \pm 1.31$ \\
\hline Control(DMSO) & $\begin{array}{c}9.22 \pm 1.75 \\
\text { N.S }\end{array}$ & $\begin{array}{c}34 \pm 2.7 \\
\text { N.S. }\end{array}$ & $\begin{array}{c}38.3 \pm 2.9 \\
\text { N.S. }\end{array}$ & $\begin{array}{l}5.55 \pm 1.65 \\
\text { N.S. }\end{array}$ & $\begin{array}{c}232.1 \pm 6.8 \\
\text { N.S. }\end{array}$ & $\begin{array}{c}5.52 \pm 1.5 \\
\text { N.S. }\end{array}$ \\
\hline $\begin{array}{l}\text { Compound } 16 \\
\text { (300 mg/kg.b.w) }\end{array}$ & $\begin{array}{c}10.1 \pm 1.3 \\
\text { N.S }\end{array}$ & $\begin{array}{c}36 \pm 2.44 \\
\text { N.S }\end{array}$ & $\begin{array}{c}40.5 \pm 2.62 \\
\text { N.S }\end{array}$ & $\begin{array}{l}5.9 \pm 1.8 \\
\text { N.S }\end{array}$ & $\begin{array}{c}240 \pm 6.4 \\
\text { N.S }\end{array}$ & $\begin{array}{c}5.72 \pm 1.4 \\
\text { N.S }\end{array}$ \\
\hline
\end{tabular}

Compared with control, ${ }^{a} \mathrm{p}<0.001$

N.S. Non- significant 